\title{
A Procedural Focus on Unlimited Shareholder Liability
}

\section{Citation}

Hansmann, Henry, and Reinier Kraakman. 1992. "A Procedural Focus on Unlimited Shareholder Liability." Harvard Law Review 106 (2): 446. https://doi.org/10.2307/1341705.

\section{Permanent link}

http://nrs.harvard.edu/urn-3:HUL.InstRepos:41426678

\section{Terms of Use}

This article was downloaded from Harvard University's DASH repository, and is made available under the terms and conditions applicable to Other Posted Material, as set forth at http:// nrs.harvard.edu/urn-3:HUL.InstRepos:dash.current.terms-of-use\#LAA

\section{Share Your Story}

The Harvard community has made this article openly available.

Please share how this access benefits you. Submit a story.

\section{Accessibility}




\title{
A PROCEDURAL FOCUS ON UNLIMITED SHAREHOLDER LIABILITY
}

\author{
By Henry Hansmann ${ }^{*}$ and Reinier Kraakman ${ }^{* *}$
}

\section{INTRODUCTION}

In a recent article $^{1}$ we criticized the traditional case for limiting shareholder liability for corporate torts and developed the case for an alternative rule of pro rata shareholder liability for tort damages exceeding a corporation's net worth. We concluded by challenging the proponents of limited liability to provide further justification for their position. Two scholars accepted our challenge: Professor Janet Cooper Alexander, writing in this issue of the Harvard Law Review, ${ }^{2}$ and Professor Joseph A. Grundfest, writing in the Yale Law Journal. ${ }^{3}$

Our original article anticipated that the best case for retaining limited liability would not rest on a traditional account of its contribution to the efficient functioning of the capital markets. Rather, we stated that the best arguments for the existing regime would be largely unrelated to the functional characteristics of the corporate form or the securities markets. Prominent among these arguments was "a conflict of law issue: without careful attention to extraterritorial enforcement, it would not be easy to implement unlimited liability in one jurisdiction while other jurisdictions retained a limited liability rule."

Judging from the responses of our critics, our prediction was correct. Professors Alexander and Grundfest do not seek to resuscitate the traditional corporate and tort law arguments for unlimited liability. Rather, both authors base their arguments largely on procedural obstacles to the enforcement of unlimited liability across jurisdictions. Professor Alexander focuses on the difficulties of inter-jurisdictional enforcement within the United States, while Professor Grundfest focuses on the international context.

We welcome the efforts of Professors Alexander and Grundfest to refine the debate over limited liability by developing a set of issues

* Harris Professor of Law, Yale University.

** Professor of Law, Harvard University. For helpful discussions and comments, we would particularly like to thank Akhil Amar, Lea Brilmayer, Owen Fiss, Geoffrey Hazard, Jed Rubenfeld, and Joseph Singer.

I See Henry Hansmann \& Reinier Kraakman, Toward Unlimited Shareholder Liability for Corporate Torts, I0o YALE L.J. I879 (199I).

2 See Janet Cooper Alexander, Unlimited Shareholder Liability Through a Procedural Lens, I06 HARV. L. REV. 387 (I992).

3 See Joseph A. Grundfest, The Limited Future of Unlimited Liability: A Capital Markets Perspective, IO2 YALE L.J. 387 (1992).

${ }^{4}$ Hansmann \& Kraakman, supra note I, at 1933. 
that, we all agree, are central to the choice of liability regimes. Their efforts have not convinced us, however, that an unlimited liability regime is infeasible. We respond here to Professor Alexander's discussion of procedural issues within the American context. Our detailed response to Professor Grundfest appears elsewhere. ${ }^{5}$

\section{Federal-Level Versus State-LeVel Implementation}

Our original article devoted only a few brief paragraphs to the doctrinal problems of choice of law and personal jurisdiction raised by unlimited shareholder liability. ${ }^{6}$ It is with these paragraphs that Professor Alexander's article takes issue.

The brevity of our discussion of these questions did not reflect a view that procedure is unimportant. Indeed, we devoted substantial attention to other procedural issues, such as the manner of determining the date on which liability would attach to shareholders in multiplaintiff litigation. ${ }^{7}$ We did feel, however, that our first task was to demonstrate the feasibility and wisdom of unlimited liability as matters of substantive tort and corporate law. Moreover, we believed that an analysis of the procedural issues raised by unlimited liability required a clear understanding of the underlying substantive issues.

Our discussion of interstate enforcement in the original article focused on the situation in which one or more individual states seek to adopt unlimited liability without the benefit of federal legislation. This was not because, as Professor Alexander infers, ${ }^{8}$ we preferred implementation at the state level. Rather, it was simply to suggest that experimentation with unlimited liability at the state level need not await federal legislation.

We quite agree with Professor Alexander that implementing unlimited liability through federal legislation is the preferable course. Toward the end of her article, Professor Alexander discusses specific federal legislation that, she argues, not only passes constitutional muster, but also meshes nicely with other procedural reforms for the types of mass tort litigation that are most likely to bankrupt publicly-traded corporations. At bottom, therefore, Professor Alexander's article strongly complements our own work by carefully describing a plausible procedural mechanism for implementing unlimited liability.

If Professor Alexander had said no more than this, we would simply thank her. Much of Professor Alexander's article, however, is devoted to arguing that without federal legislation it would be infeas-

5 See Henry Hansmann \& Reinier Kraakman, Do the Capital Markets Compel Limited Liability? A Response to Professor Grundfest, IO2 YALE L.J. 427 (I992).

${ }^{6}$ See Hansmann \& Kraakman, supra note $\mathrm{I}$, at I92I-23.

7 See id. at $1896-99$.

${ }^{8}$ See Alexander, supra note 2, at $39 \mathrm{I}-92$. 
ible, and indeed unconstitutional, to adopt unlimited shareholder liability in tort. 9 Contrary to our suggestion, then, she asserts that individual states could not proceed on their own. Because we believe that Professor Alexander is mistaken about the difficulties of statelevel adoption, further clarification of the issues is in order.

\section{Issues Presented By State-LeVel Implementation}

In our original discussion of conflict of laws and personal jurisdiction, we wrote that "any state should be able to adopt unlimited shareholder liability for corporate torts, either by legislation or by judicial decision, for application to any tort claim to which the state's tort law applies, regardless of the state of incorporation of the corporate defendant."10 When Professor Alexander quotes this sentence in the first paragraph of her article ${ }^{11}$ (and elsewhere), she elides the words "should be able to" and substitutes the paraphrase "could." The change is subtle, but significant. We meant to make a statement with a normative cast: that the most coherent and thoughtful interpretation of current doctrine would support our position. Professor Alexander's paraphrase suggests, instead, that we were making a positive prediction that well-settled doctrine would compel the courts of all states to accept a single state's assertion of unlimited liability for out-of-state shareholders - a stronger statement than we wished to make.

To focus our debate with Professor Alexander more clearly, two hypothetical examples may be helpful.

I. Flexxon. In the first example, a widower living in Massachusetts invests his entire savings in the stock of Flexxon, a large oil company incorporated in Delaware. Like many shareholders, he knows virtually nothing about either corporate law or the locations of Flexxon's operations and legal domicile. He only knows that Flexxon is reputed to be a good company. It is his misfortune that Flexxon, which does no regular business in Illinois, must one day ship oil down the Mississippi river. The oil spills, and the Illinois courts apply a novel theory of environmental torts to award actual and punitive damages of $\$ 40$ billion against Flexxon, which exceeds the company's $\$ 30$ billion net worth. If Flexxon is made to pay it will be bankrupted, rendering the widower's stock valueless and thus forcing him into penury.

2. Union Carbicide. In the second example, a Massachusetts investor with a well-diversified portfolio of \$100 million owns $\$ 50,000$ 
worth of stock in the Union Carbicide Company, a Delaware corporation that manufactures toxic chemicals. Like most sophisticated investors, she knows that Union Carbicide maintains its large profits by minimizing its investments in safety, particularly at its antiquated plant in Peoria, Mlinois. Likewise, she knows that each Union Carbicide plant is incorporated as a separate Delaware subsidiary, that the Peoria subsidiary has only $\$ 20$ million in net assets, and that the parent company itself maintains a debt-equity ratio of $90 \%$ in order to minimize the amount of assets available to satisfy tort judgments. Finally, the investor is also aware of recent legal developments in Illinois and Delaware. Six years ago, the Illinois legislature adopted an act providing for unlimited pro rata shareholder liability, to be applied prospectively to all corporate torts committed in Illinois regardless of the tortfeasor's legal domicile - five years or more after the statute's enactment. The act further granted the Mlinois courts personal jurisdiction over out-of-state shareholders to aid its enforcement. In the meantime, however, Delaware revised its corporation law to provide clearly that shareholders, including parent corporations, are not liable for a corporation's torts as long as corporate formalities are observed - something that Union Carbicide and its subsidiaries have always done.

This year, toxic gases leaked from the Peoria plant, killing 2,000 people outright and cruelly maiming 8,000 more. The Illinois courts sustained a conservative total of $\$ \mathrm{IO}$ billion in damage awards. Having exhausted the subsidiary's $\$ 20$ million in net assets, the Illinois plaintiffs now seek to invoke the Illinois shareholder liability act to satisfy this judgment out of the $\$ 5$ billion in net assets of the parent corporation, and also seek to recover the nearly $\$ 5$ billion in remaining damages from the parent corporation's shareholders. If the Illinois plaintiffs are successful, our Massachusetts shareholder will thus lose not only her $\$ 50,000$ investment, but also pay nearly $\$ 50,000$ in excess damages.

Viewed in terms of these two hypothetical examples, we read Professor Alexander's article as saying the following: (I) Under prevailing doctrine concerning choice of law and jurisdiction, Illinois plaintiffs, suing in Illinois courts, could collect $\$ 30$ billion from Flexxon and bankrupt the widower. (2) On the other hand, the plaintiffs in the Union Carbicide case would be able to collect only $\$ 20$ million against the assets of the Peoria subsidiary. The plaintiffs would recover nothing from the parent corporation, much less from the personal assets of its shareholders (including our Massachusetts investor), because choice of law doctrine would apply Delaware law on the issue of shareholder liability. Thus, not only would the Massachusetts investor escape personal liability, but also her $\$ 50,000$ investment in Union Carbicide stock would retain most of its value as well. Moreover, this interpretation of choice of law doctrine may well 
be mandated by the Constitution. (3) Even if Illinois law could be applied to the question of the substantive liability of the parent corporation or its shareholders, the Mllinois courts could not constitutionally assert personal jurisdiction over the investor with respect to her $\$ 50,000$ share of the damages that cannot be paid out of Union Carbicide's assets.

We disagree that current doctrine compels the conclusions described in (2) and (3). We briefly sketch our reasoning here on both the conflict of laws and the jurisdictional issues involved. 12

\section{Conflict of Laws: The Internal Affairs Doctrine}

Professor Alexander argues that the "internal affairs doctrine" requires that shareholder liability for corporate torts be governed by the law of the state of incorporation rather than by the law of the state in which the tort occurred. ${ }^{13}$ The authority she cites for this proposition is the Restatement (Second) of Conflict of Laws. ${ }^{14}$

The Restatement, however, is far less clear about the issue than Professor Alexander suggests. The comments to sections 301 and 302 - the sections setting forth the general rule - distinguish between such clearly internal matters as the adoption of by-laws and methods of shareholder voting, which are governed by the law of the state of incorporation, and matters that involve third parties, such as "the commission of torts." 15 The Restatement provides that "[t]here is no reason why corporate acts of the latter sort should not be governed by the local law of different states." 16 Section 307 , which deals more

12 Many of the practical problems associated with procedural implementation of unlimited pro rata liability that Professor Alexander raises in Part III of her article are tied to her views on personal jurisdiction and conflict of laws, and thus do not raise separate issues.

Professor Alexander is probably correct, however, in her assertion that, when litigation involves multiple plaintiffs, there could be substantial complexity in seeking to satisfy judgments. See Alexander, supra note 2, at 421-24. But it does not follow that limited liability in tort should be retained. First, as we noted in our original article, tort litigation that bankrupts widely-held corporations is likely to remain relatively rare after our proposed reform. Rather, litigation would in most cases only involve shareholders of closely-held firms and, in particular, the corporate parents of subsidiaries, see Hansmann \& Krakman, supra note 1, at 1932, and the latter types of cases will generally not give rise to the complexities Professor Alexander discusses. Second, plaintiffs will have a strong incentive to alleviate these complexities by consolidating either their original tort suits or their collection efforts. Third, complexities could be substantially avoided by enacting federal legislation of the type that Professor Alexander describes. Fourth, even if the occasional large case encountered some complexity, it may be a price well worth paying to remove the highly distortionary incentives created by current limited liability doctrine.

${ }^{13}$ See Alexander, supra note 2, at 4ro-15.

14 See id. at 410-II \& nn.II7-I9.

15 Restatement (SECOND) of Conflicts of LAW $\$ 302 \mathrm{cmt}$. e (1971)

${ }^{16} I d$. 
specifically with shareholder liability, states only that the law of the state of incorporation shall determine a shareholder's liability to a corporation's "creditors for corporate debts." 17 The brief comments to section 307 give no examples amplifying on the latter phrase, and in particular, make no reference to tort liability.

Although the language of section 307 might be read to include tort claimants, notwithstanding sections 301 and 302 , the better wisdom is to confine its language to voluntary contractual creditors. ${ }^{18}$ For reasons we discussed in our original article, limited liability makes eminent sense as the default rule for a corporation's voluntary creditors. Moreover, the law of the state of incorporation is clearly the law most appropriate to govern the scope of shareholder liability to contractual creditors: that state's law provides a clear, consistent, and predictable means for the corporation, its shareholders, and its creditors to determine which assets are being pledged as security for various obligations, and to adjust the cost of credit accordingly. It is presumably this logic that lies behind section 307 .

But the same reasoning by no means extends to a corporation's involuntary creditors. As the Union Carbicide hypothetical illustrates, allowing a state like Delaware to determine the scope of tort liability for companies incorporated under its law invites gross opportunism on the part of both the state and the shareholders who invest in its corporations.

If, for example, Delaware amended its corporation law to limit corporate liability for tort judgments to the par value of the shareholder's stock (which most corporations set at zero), we assume that nobody would seriously argue that the internal affairs doctrine requires that the new rule be respected. And if Delaware adopted a restrictive veil-piercing rule that (together with the state's liberal policy toward the creation of subsidiary corporations) effectively permitted the same result, it is not obvious that, under a reasonable conflict of laws doctrine, such a rule deserves any more respect than would the par value rule.

In support of her interpretation of the Restatement, and of her assertion that this interpretation may be mandated by the Constitution, Professor Alexander cites only two cases. Principal among these is CTS Corp. v. Dynamics Corp. of America. ${ }^{19}$ But CTS involved only matters of internal corporate governance (shareholder voting) and

17 Id. $\S 307$.

${ }^{18}$ In a footnote, Professor Alexander contests our reading of the "clear language" of the Restatement. Alexander, supra note 2 , at $4 \mathrm{I} 4$ n.129. But we, like the courts, find that language thoroughly - almost studiedly - ambiguous. Moreover, the Restatement is neither a statute nor (as we emphasize below) a constitution, but rather just common law doctrine that can be reinterpreted or simply rejected and replaced by the courts of any state.

${ }^{19} 48$ I U.S. 69 ( 1987 ). 
not relations with a corporation's creditors, whether voluntary or involuntary. ${ }^{20}$

On the other hand, there is substantial precedent, not mentioned by Professor Alexander, that supports our own interpretation of choice of law doctrine. To begin with, the reporter's note to section 307 of the Restatement states:

A state may impose liability upon a shareholder of a foreign corporation for an act done by the corporation in the state, if the state's relationship to the shareholder is sufficient to make reasonable the imposition of such liability upon him. See Thomas v. Matthiessen, 232 U.S. 22I (I9I4); Pinney v. Nelson, I83 U.S. I44 (I90I). ${ }^{21}$

The two Supreme Court cases cited both involve the provision in California's corporation statute that, until I93I, applied a rule of pro rata unlimited shareholder liability not only to corporate torts, as we propose, but also to a corporation's contractual debts, and extended that rule to any foreign corporation doing business in California. ${ }^{22}$ The Supreme Court held in both cases (per Justice Holmes in Thomas) that California could apply its statute even to out-of-state shareholders of a firm incorporated in another state whose law specifically provided for limited shareholder liability. ${ }^{23}$

More recent precedent follows similar lines. In First National City Bank v. Banco Para El Comercio, ${ }^{24}$ the Supreme Court refused to apply the incorporating country's law to determine whether the formalities of the corporate form could be invoked to defeat a counter-

${ }^{20}$ See id. at 73-75. The other case cited by Professor Alexander, Kamen v. Kemper Fin. Servs., Irr S. Ct. I 7rY (rggr), also concerns matters of internal corporate governance; moreover, it involves only gap-filling in the interpretation of a federal statute. See id. at 1715, 1717.

21 RESTATEMENT (SECOND) OF CONFLICT OF LAWS § 307 reporter's note (197I).

22 See Thomas v. Matthiessen, 232 U.S. 221, 233 (I914); Pinney v. Nelson, 183 U.S. 144, 145-46 (rgor).

23 In a responding footnote, Professor Alexander seeks to distinguish Pinney and Thomas on the theory that the shareholders involved could be understood as having accepted the application of California corporation law to their activities. See Alexander, supra note 2, at 412 n.121. But in Thomas, the Court is very clear that "the defendant and his associates . . . intended their liability to be controlled by the laws of Arizona," where their company was incorporated, and not by the laws of California. Thomas, 232 U.S. at 233. The preincorporation agreement that Professor Alexander refers to, like the corporation's charter, specifically provided that the shareholder would not be personally liable for the corporation's debt. The Court simply stated that this agreement (and the corporation's charter) would not be given effect because the same agreement contemplated that the corporation would do business in California. See id. at 23435. In short, the Court clearly rejected the shareholder's strong and explicit efforts to avoid California's unlimited liability statute by incorporating in another state, by appealing to specific charter provisions, or by relying upon other contractual commitments. In effect, the Court stated that doing business in California by itself necessarily involved accepting California's unlimited shareholder liability rule.

${ }^{24} 462$ U.S. 6 II (I983). 
claim asserted by one of the corporation's debtors. Justice O'Connor, writing for the Court, stated:

As a general matter, the law of the state of incorporation normally determines issues relating to the internal affairs of a corporation. Application of that body of law achieves the need for certainty and predictability of result while generally protecting the justified expectations of parties with interests in the corporation. See Restatement (Second) of Conflict of Laws $\S 302 \ldots$. . . Different conflicts principles apply, however, where the rights of third parties external to the corporation are at issue. See Restatement (Second) of Conflict of Laws, supra, $\S$ 3or. To give conclusive effect to the law of the chartering state in determining whether the separate juridical status of its instrumentality should be respected would permit the state to violate with impunity the rights of third parties under international law while effectively insulating itself from liability in foreign courts. ${ }^{25}$

Following this logic, other federal courts have also recently rejected defendants' arguments that the law of the incorporating jurisdiction must be applied in determining whether to pierce the corporate veil. ${ }^{26}$ Because most of these cases involve contract claims, they actually present a weaker justification for rejecting the incorporating state's law than do the tort cases that concern us.

We do not wish to claim that the power of one state to regulate companies incorporated in another state is well settled. It is not. ${ }^{27}$ We wish simply to emphasize that not only logic but also established doctrine provide substantial support for the approach we advocate for corporate torts.

\section{Personal Jurisdiction}

Professor Alexander asserts that, in a case like our Union Carbicide hypothetical, it would be an unconstitutional violation of due process

$25 I d$. at $621-22$ (footnote omitted).

26 See Foster v. Berwind Corp., No. 90-0857, I99I WL 2 I666, * (E.D. Pa. Feb. 13, I99I); Itel Containers Int'l Corp. v. Atlanttrafik Express Serv., No. 86 Civ. 13 33 (RCL), I988 WL $75262, *_{4}$ (S.D.N.Y. July $x_{3}$, I988).

In a responding footnote discussing these two cases, see Alexander, supra note 2, at 4I2 n.121, Professor Alexander seems to confuse the substantive law of veil-piercing (which, in all the jurisdictions in question in these cases, basically followed the traditional conservative doctrine rather than the radically different rule that we proposed in our original article) with the procedural conflict of laws question of whether the incorporating state's law or the forum state's law should be applied in determining whether the veil ought to be pierced.

27 See Harry G. HENN \& John R. Alexander, Laws of Corporations and Other BUSINESS ENTERPRISES 217 (3d ed. I983); Jed Rubenfeld, State Takeover Legislation and the Commerce Clause: The "Foreign" Corporations Problem, 36 CLEv. ST. L. REv. 355, 376-82 (I988). As Professor Rubenfeld notes, the distinction between "internal" and "external" affairs has remained so vague that courts have been able to classify almost any form of corporate activity within either category, leaving the internal affairs doctrine a relatively empty formulation and arguing strongly against any effort to constitutionalize it. 
for Illinois to exert jurisdiction over a Massachusetts shareholder of a Delaware corporation. ${ }^{28}$ We disagree. We believe that such jurisdiction comports well with the "traditional conception of fair play and substantial justice"29 that underlies the constitutional standard of due process.

\section{A. General Principles}

More particularly, following the standards quoted by Professor Alexander, ${ }^{30}$ a shareholder in a corporation that has committed a tort in the forum state can appropriately be said to have "'purposefully avail[ed] [her]self of the privilege of conducting activities within the forum State," "31 or "'purposefully directed' [her] activities at residents of the forum." 32 The very object of stock ownership is to avail oneself of the privilege of conducting business in all the jurisdictions in which the corporation is active. And surely, our "traditional conception of fair play and substantial justice" is not offended by requiring a shareholder who participates pro rata in the profits of a business, without upper bound, also to bear all of its costs, pro rata and without upper bound, rather than forcing some of these costs onto involuntary third parties such as tort victims.

It is presumably under an implicit notion of "purposefully availing" that current law would allow Illinois, in our Flexxon hypothetical, to assert jurisdiction sufficient to appropriate all of the widower's wealth as tort damages, even though neither the widower's place of residence, nor Flexxon's place of incorporation, nor Flexxon's corporate assets, are located in Illinois. Indeed, everyone, including Professor Alexander, evidently agrees that the widower who invests his life savings in Flexxon effectively subjects himself to the jurisdiction of the Illinois courts to the full extent of his investment. ${ }^{33}$ Our proposed rule of pro rata shareholder liability merely alters this convention so that shareholders, upon investing in a corporation, are put on notice that they risk substantive liability not just up to the amount they invest, but rather, up to their pro rata share of all tort damages assessed

${ }^{28}$ See Alexander, supra note 2 , at 394-404.

${ }^{29}$ International Shoe Co. v. Washington, 326 U.S. 310, 320 (1945).

30 See Alexander, supra note 2, at 395 .

31 World-Wide Volkswagen Corp. v. Woodson, 444 U.S. 286, 297 (r980) (quoting Hanson v. Denckla, 357 U.S. 235, 253 (1958)).

32 Burger King Corp. v. Rudzewicz, 47 I U.S. 462, 472 (r985) (quoting Keeton v. Hustler Magazine, Inc., 465 U.S. 770,774 (1984)).

${ }^{33}$ In a responding footnote, see Alexander, supra note 2, at 398 n.54, Professor Alexander seems to miss the point of our Flexxon hypothetical, which was precisely to emphasize how arbitrary it is, for the purposes of procedure, to attribute too much metaphysical force to the concept of the corporation as a "separate legal entity." 
against the corporation. Assuming that shareholders receive adequate notice of the new rule, there seems no reason why Illinois courts should not be able to assert jurisdiction sufficient to collect the full damages for which shareholders are liable under the substantive law.

The issue of notice here is, of course, important. Any effort to impose unlimited liability retroactively should give us pause as a matter of due process. But when, as we proposed in our original Article, ${ }^{34}$ a tort rule of unlimited liability is well publicized and applied only prospectively, every investor will know that a purchase of stock puts her personal assets at risk. The investor who wishes to avoid serious risk of personal liability can do so by confining her investments to (a) non-equity assets such as bonds and savings deposits; (b) companies that are adequately capitalized or insured; or (c) highly diversified mutual funds. As an alternative, she can purchase portfolio insurance.

Professor Alexander emphasizes direct control as a basis for jurisdiction, and asserts that "[a] passive shareholder of a public corporation ... lacks the control over the actions of an in-state actor (the corporation) that characterizes the principal-agent, veil-piercing, and partnership examples." 35 Consequently, she argues, jurisdiction that can be asserted in the latter cases does not extend to the former. But a major point of our article is precisely that a narrow notion of direct control is inappropriate to an analysis of corporate torts, as it is to analyzing corporate policies in general. Under unlimited liability, small investors (indeed, all investors) who cannot control a corporation's affairs directly will decline to invest in the stocks of companies that do not adequately compensate investors for the liability risks that they impose. The resulting decline in stock prices will pressure management to change its policies, lest the stock be purchased by somebody who can assemble sufficient shares to oust the management and change the corporation's policies. In short, all shareholders participate importantly in corporate control through the market.

A further consideration supporting Illinois's assertion of jurisdiction - one that is critical from the perspective of due process - is that shareholders do not need to assume the burden of appearing in court in the forum state "to defend the suit away from [their] home."36 All questions of both corporate and shareholder liability should be settled in the initial tort suit against the corporation that is brought in the forum state. ${ }^{37}$ In this suit, the corporation should act as the

34 See Hansmann \& Kraakman, supra note I, at I923.

35 Alexander, supra note 2, at 40 r.

36 International Shoe Co. v. Washington, 326 U.S. 3Io, 3 I 7 (I945).

37 Indeed, individual shareholders should not be permitted to raise individual defenses to the substantive tort suit. Rather, the only issue that should be open for them to contest is whether 
exclusive representative of the shareholders, just as it now does in tort actions brought under limited liability regimes (as in the Flexxon hypothetical).

Finally, the state in which a tort occurs - Illinois in our hypothetical - has an obvious interest in adjudicating all aspects of the tort suit, including the liability of individual shareholders. This interest is surely as strong, and arguably more legitimate, than that of either the shareholder's state of residence or the corporation's legal domicile. For this reason, permitting Illinois to exercise jurisdiction furthers rather than frustrates the sovereignty concerns that Professor Alexander emphasizes. ${ }^{38}$ Indeed, denying jurisdiction would shift sovereignty over Mllinois's industrial activity to states - Massachusetts or Delaware - whose principal interest is to externalize costs onto Illinois residents.

\section{B. Is There Contrary Precedent?}

Professor Alexander discusses three principal cases in which, she claims, "the Supreme Court has rejected the jurisdictional premises of Professors Hansmann's and Kraakman's state tort law approach." 39 We disagree with her interpretation of each of these cases.

The first of these cases is Shaffer $v$. Heitner, ${ }^{40}$ which Profesisor Alexander characterizes as holding that "mere ownership of shares does not satisfy the minimum contacts test, even when the corporation is incorporated in the state." 41 We read that case much differently. Shaffer involved a statute that purported to give Delaware courts quasi in rem jurisdiction over any nonresident who owned property in Delaware regardless of whether this property was related to the cause of action at issue. The defendants in Shaffer owned stock in a Delaware corporation. The Delaware courts had characterized this stock as in-state property, thus giving them jurisdiction over the defendants under the statute. The Supreme Court reversed, holding simply that the presence of property in a state, without more, does not suffice to give the state personal jurisdiction over the property owner "where the property . . . is completely unrelated to the plain-

they were shareholders at the time relevant for determining liability. See Hansmann \& Kraakman, supra note $\mathrm{I}$, at $\mathrm{Igo0}$.

On the other hand, it should presumably be open to shareholders, in appropriate cases, to contest whether the corporation is acting as an adequate representative of the shareholders' interests as a class.

38 See Alexander, supra note 2 , at $402-03$.

39 Id. at 403 .

40433 U.S. 186 ( 1977$)$.

41 Alexander, supra note 2, at 396. 
tiff's cause of action." 42 The Court specifically noted that "[t]he presence of property may ... favor jurisdiction in cases [in which] the cause of action is . . . related to rights and duties growing out of that ownership."43 Thus, Shaffer is fully consistent with basing jurisdiction on stock ownership when, as under our proposed pro rata liability rule, stock ownership is the very predicate of substantive tort liability, and the amount of stock owned determines the damages for which the defendant is liable. ${ }^{44}$

In support of her reading of Shaffer, Professor Alexander also cites Keeton v. Hustler Magazine, Inc. ${ }^{45}$ in which the Supreme Court rejected, in a brief footnote, the proposition that jurisdiction over a corporation automatically establishes jurisdiction over that corporation's holding company. ${ }^{46}$ We did not argue, however, that jurisdiction over a corporation always implies jurisdiction over that corporation's shareholders, or even over a parent corporation. In many situations, such jurisdiction would arguably be incorrect. This may be true when, for example, important defenses are available to the shareholder that are not available to the corporation, so that it is appropriate for the shareholder to have independent representation.

Finally, Professor Alexander invokes World-Wide Volkswagen Corp. v. Woodson ${ }^{47}$ in which the Supreme Court held that Oklahoma could not obtain jurisdiction over a New York Volkswagen dealer or that dealer's wholesale distributor, also located in New York, in a tort suit seeking damages for an accident in Oklahoma involving an automobile purchased from the New York dealer and subsequently driven to Oklahoma. ${ }^{48}$ Professor Alexander argues that jurisdiction to assess pro rata personal liability against corporate shareholders would be even more difficult to justify, and thus falls outside constitutional limits. ${ }^{49}$

42 Shaffer, 433 U.S. at 208-09 (emphasis added).

43 Id. at 208.

44 In a responding footnote, see Alexander, supra note 2, at 399 n.58, Professor Alexander misreads our argument concerning Shaffer. We are not claiming that Mlinois should have jurisdiction over the shareholder in Union Carbicide based on a theory that she owns "property" in the form of a stock certificate, much less are we concerned with arguments about the state in which those certificates are deemed to reside. Indeed, the central point of the Court's opinion in Shaffer, as we read it, is precisely to reject such formalistic notions of quasi in rem jurisdiction in favor of a general functional approach to jurisdiction. The Illinois courts should have jurisdiction over the Union Carbicide shareholder because she is an owner of a company that committed a tort in Illinois. Or, if we are to speak in terms of property, the relevant piece of property that she owns is the chemical plant in Peoria, Mlinois that caused the tort. Her shares of Union Carbicide stock are simply the tokens of that ownership.

45465 U.S. 770 ( 1984$)$.

${ }^{46}$ See id. at $78 \mathrm{I}$ n.r3. Because the First Circuit did not inquire into the propriety of jurisdiction over the parent firm, the Court remanded the case for further proceedings. See id.

${ }^{47} 444$ U.S. 286 ( 1980 ).

48 See id. at 295.

49 See Alexander, supra note 2, at 397-98. 
But important differences exist between World-Wide Volkswagen and our proposal for unlimited liability, each of which is illustrated by our Union Carbicide example. First, in strong contrast to the dealer and distributor in World-Wide Volkswagen, the shareholders in Union Carbicide need not bear the burden of hiring counsel and appearing personally to defend themselves in the courts of a distant state. Rather, they have a representative, the corporation, that is perfectly situated to defend them in the tort suit and that must, in fact, defend the suit in any event. Second, the relationship between Union Carbicide's shareholders and the corporation's tortious activity is far closer than that between the dealer and distributor in WorldWide Volkswagen and the accident caused by the auto they had sold. The shareholders, after all, own the plant that caused the tort. If the New York dealer had owned and operated the car that caused the accident in Oklahoma, World-Wide Volkswagen would have been a very different case. Third, the plaintiffs in World-Wide Volkswagen were not residents of Oklahoma, but rather of New York - the state in which the defendants resided and in which the purchase that formed the basis of the alleged liability took place. The plaintiffs simply happened to be driving through Oklahoma when the accident involved occurred. By contrast, because the plaintiffs in our Union Carbicide hypothetical are residents of the forum state, the state's legitimate interest in adjudicating the dispute is enhanced. Moreover, it would be burdensome for the plaintiffs to litigate elsewhere. ${ }^{50}$ For all of these reasons, World-Wide Volkswagen appears to be even less apposite to jurisdiction under a pro rata liability statute than are Shaffer and Keeton.

\section{ConCLUSION}

Professor Alexander warns us against framing a reform of substantive law without attending to the procedures needed to implement it. But the reverse is equally important: procedural rules should not be viewed in isolation from the underlying substantive law. Moreover, the relevance of substance to procedure is nowhere clearer than in the

50 Although the Court did not address this third point in its opinion in World-Wide Volkswagen, it did emphasize the issue in a subsequent case with very similar facts. See Asahi Metal Indus. Co. v. Superior Court, 480 U.S. I02, II4-I6 (I987).

In a responding footnote, Professor Alexander emphasizes that "[t]he tort, however, occurred in Oklahoma." Alexander, supra note 2, at 398 n.54. But another way of stating the point we are making here is that one could well argue instead that the tort occurred in New York when the defendants sold the plaintiffs a defective car. 
case of shareholder liability for corporate torts, in which the procedural issues closely trace the substantive issues. Essentially the same arguments that support unlimited shareholder liability as a matter of substantive policy also support the conflict of laws and jurisdictional doctrines that are necessary and appropriate to enforce that liability. 